\title{
coloniality and/as development in Kashmir: econonationalism
}

Feminist Review Issue 128, 114-131 (C) 2021 The Author(s) Article reuse guidelines: sagepub.com/journals-permissions DOI: $10.1177 / 01417789211016490$

www. feministreview.com

@SAGE

\section{Nitasha Kaul}

\section{abstract}

This article identifies the colonial imperative of 'we must develop them, with or without their consent', which is used by the Indian state in order to dominate Kashmiri Muslims, and argues that this notion of development combines patriarchal silencing of the subjugated as well as a gendered fantasy of liberating oppressed Kashmiri women and minorities. While the colonial nature of Indian rule over Kashmir has been a long-term phenomenon, the focus in this article will primarily be on a specific political transformation imposed by the Indian state since August 2019 , when even the pretence of autonomy and recognition was given up, and all phenomena constituting coloniality became conspicuous and acute. Adopting a feminist lens, I highlight nine features of contemporary Indian coloniality in Kashmir: denial of consent, paternalism, violence, enforced silencing, lack of accountability, arbitrariness, divide and rule, humiliation and a specious idea of development. I further argue that such a notion of coloniality as development is better understood as 'econonationalism' (akin to homonationalism and femonationalism), where the supposed liberatory ideas are rhetorically deployed to mask a dehumanising subjugation.

\section{keywords}

development; Kashmir; India; coloniality; gender; econonationalism; patriarchy; Article 370; human rights 
For it is not true that there are some good colons and others who are wicked. There are colons and that is it.

(Sartre, $2001[1964 / 1956]$, p. 32)

Postcolonial and decolonial scholars have contributed to a vast literature interrogating the dynamics of imperial-colonial projects, often with an exclusive focus on the impacts of European colonialisms on large parts of Asia, Africa and the Americas (Bhambra, 2014). However, this prodigious criticality has not been adequately brought to bear upon the actions of the formerly colonised states in the non-West as they have often sought to recreate the colonial theatres in their own peripheries. When it comes to Indian-administered Kashmir, the multifaceted violence of the Indian state towards Kashmir cannot be subsumed away in the name of India being a non-Western postcolonial entity. India's actions in Kashmir were not seen as colonial because India itself had been colonised. However, colonialism is not exclusively a Western prerogative, and the 'moral wound of colonialism' has been weaponised by formerly colonised states to deny their own colonialism (Kaul, 2020b).

Like patriarchy with its implicit and explicit assumptions and practices that reinforce systemic gendered inequities, colonialism whether formally or informally enacted carries within it an assumed moral superiority and economic rationality. Paternalism and violent policing of behaviour of the subjugated go hand in hand. The territorial dimension of colonial rule is anchored by using the techniques of military occupation and bureaucratic control to deny a subjugated population their political aspirations for freedom or self-rule. In each of these senses, the Kashmiri population in Jammu and Kashmir, with a focus on Muslim-majority Kashmir Valley under Indian control, has been subjected to a long-running exercise of power that is colonial.

With every passing year, as democratic rights come to mean much less in India, ${ }^{1}$ the usual rationales given for why power is exercised in this way by the Indian state upon Kashmiris wear thin. India's rule should be understood as 'the masculinist patriarchal bureaucratic governmentality of a postcolonial emerging power with hubris that seeks to uncompromisingly possess Kashmir' (Kaul, 2018, p. 138). Coloniality involves feminisation (Nandy, 1983) as well as hyper-masculinisation of the colonised bodies with the purpose of legitimising control, and we have witnessed a rapid acceleration of this in recent months in Indian-administered Kashmir. Kashmiri female bodies are projected as beautiful, fragile and vulnerable to victimisation by hyper-masculine Kashmiri-Muslim patriarchy, thus calling for being 'saved' by not only the progressive feminist Indians but also by, rather than from, the Indian masculinist nation state.

This article identifies the colonial imperative of 'we must develop them with or without their consent' that is used by the Indian state in order to dominate Kashmiri Muslims, and argues that this notion of

\footnotetext{
${ }^{1}$ State repression of protests against the Citizenship (Amendment) Act, 2019 (CAA) (2019), the National Register of Citizens (NRC) and the 2020 Farm Laws (Essential Commodities [Amendment] Act, 2020, 2020; Farmers [Empowerment and Protection] Agreement on Price Assurance and Farm Services Act, 2020, 2020; Farmers' Produce Trade and Commerce [Promotion and Facilitation] Act, 2020, 2020) has seen the Indian state actively use sedition laws against dissent, while right-wing vigilante attacks on protesters and on several universities in India have gone unchecked.
} 
development combines patriarchal silencing of the subjugated as well as a gendered fantasy of liberating oppressed Kashmiri women and minorities. While the colonial nature of Indian rule over Kashmir has been a long-term phenomenon, the focus in this article will primarily be on a specific political transformation imposed by the Indian state since August 2019, when even the pretence of autonomy and recognition was given up, and all phenomena constituting coloniality became conspicuous and acute. Adopting a feminist lens, I highlight nine features of contemporary Indian coloniality in Kashmir: denial of consent, paternalism, violence, enforced silencing, lack of accountability, arbitrariness, divide and rule, humiliation and a specious idea of development. I further argue that such a notion of coloniality as development is better understood as 'econonationalism' (akin to homonationalismand femonationalism), where the supposed liberatory ideas are rhetorically deployed to mask a dehumanising subjugation.

\section{August $2019-t h e$ constitutional coup and aftermath}

Until 5 August 2019, Indian-administered Kashmir (known as 'Jammu and Kashmir' or 'J\&K' under the Indian Constitution) had de jure autonomous statehood through the provisions of Article 370 of the Indian Constitution. Both the constitutionally guaranteed autonomy and the statehood were abolished on 5 August-through what should be called a 'constitutional coup'-without any consultation with, or consent from, any Kashmiris in any capacity. ${ }^{2}$ Immediately prior to this fateful morning, tens of thousands of extra troops were brought into the already heavily militarised Kashmir Valley from India, and tourists and pilgrims were advised to leave.

Discarding the substance and rationale of the constitutional provisions and guarantees-through a baffling series of legal machinations that have been the subject of critiques by many expert lawyers-the Indian Parliament arrogated to itself the power and ability to act to make these changes in lieu of the J\&K state legislature. Through this, the constitutional autonomy of the Jammu and Kashmir state was taken away; it was simultaneously bifurcated and converted from being a state to becoming two union territories (Ladakh being one, and Jammu and Kashmir the other) to be directly administered from the centre.

As this was enacted and the special status plus statehood of Jammu and Kashmir was dismantled, a telecommunications ban covering internet, landline, mobile and text services was imposed upon the region. In addition, curfews came into force, with Section $144^{3}$ used to prevent people from gathering anywhere. Political leaders from across the ideological spectrum were placed under indefinite house arrest or detention. Hundreds of members of civil society, including academics, teachers and businesspersons, were arrested. An unverifiably large number of young persons, including children as young as 9 years old, were detained and arrested, and some were sent off to prisons in far-off places in India. No-fly lists were prepared for hundreds of Kashmiri individuals, and prominent former bureaucrats and journalists were prevented from leaving the region. Any relaxations in communication since then

\footnotetext{
${ }^{2}$ See Angana Chatterji and Nitasha Kaul's respective testimonies at the US House of Representatives hearings on Human Rights in South Asia: Views from the State Department and the Region, Panel II (US House of Representatives, Committee on Foreign Affairs, 2019), available at: https://docs.house.gov/meetings/FA/FA05/20191022/110143/HHRG-116-FA05-WstateChatterjiA-20191022.pdf [last accessed 20 May 2021] and https://docs.house.gov/meetings/FA/FA05/20191022/110143/ HHRG-116-FA05-Wstate-KaulN-20191022.pdf [last accessed 20 May 2021].

${ }^{3}$ Section 144 of The Code of Criminal Procedure (CrPC) 1973 is a colonial-era law that prohibits assembly of people. It is routinely used in Kashmir.
} 
have been piecemeal and restricted, and in some cases conditional, such as release from detention upon signing bonds to confirm that the individuals will not be speaking to the media (Kathju, 2019; The Wire, 2019c). The internet shutdown continued into 2020, making this the longest ever such instance in any democracy worldwide. ${ }^{4}$ Even as the Coronavirus pandemic began and the flow of information became essential for saving lives, only limited communication was initially restored.

This Constitutional Coup of 5 August 2019 is the apotheosis of what can best be described as the colonial exercise of power by India in Kashmir. To those who are familiar with the history and politics of the region, the most striking aspect of August 2019 is not the changes to Article 370 or the telecommunications ban per se. These moves are certainly draconian, but they represent the acceleration and deepening of what is a long-standing unaccountable exercise of power with legal impunity in the most militarised zone of occupation (CIA, 2020). The autonomy guaranteed under Article 370 had already been eroded substantially over time. What is perhaps most striking about what was done to Kashmir in August 2019 and its aftermath is the unmasking of a coloniality, clearly recognisable through substantive changes in residency laws, land ownership, environmental regulations and demography, even as it seeks to disguise itself under the liberation rationale of empowering women and other marginalised identities and ushering in 'development' for all.

\section{features of contemporary Indian coloniality in Kashmir: a feminist lens}

With the events of August 2019, a turning point was marked, which unmistakably highlighted the resonance of colonial rule. It is helpful to adopt a feminist lens and identify the similarities this colonial rule has with patriarchy ${ }^{5}$ and rape culture, where rape is recognised not as an exceptional sexual act but a product of systemic assertion of power normalised through marshalling of gendered and sexualised violent language and practices. Adopting a feminist lens, here I make nine observations on contemporary India's assertion of coloniality over Kashmir.

First, there is a denial of consent. The consent of any Kashmiri individual or collective constitutional or legal or civic body in Jammu and Kashmir was deemed irrelevant to what was imposed upon them as fait accompli, notwithstanding the claim of India to be a democracy. ${ }^{6}$ Patriarchy under-emphasises rape and sexual violence by making women subordinate to, and in proprietorial relations with, men. Coloniality is about reinforcing asymmetrical power relations and denial of agency to the colonised in how they are governed. Consent is not deemed necessary because it is the patriarch/coloniser who is the 'owner'/'caretaker' of the feminised Other/colonised. In the unilateral ending of de jure autonomous statehood, the Indian state showed no desire to seek the consent of the people directly affected.

Second, there is paternalism, where all measures are justified as being for the good of ordinary people. Indian PM Modi, in one of his first speeches after announcing the end of the autonomous statehood,

\footnotetext{
${ }^{4}$ Globally, India ranks highly in enforcing internet censorship; Jammu and Kashmir has experienced 193 occasions of internet blocks since 2016 (see Scroll.in, 2019a). One million tweets referencing Kashmir have been deleted at the request of the Indian government within the last two years (Haddad, 2019).

${ }^{5}$ On patriarchal colonialism, see Spencer-Wood, 2016.

${ }^{6}$ Only right-wing pro-Hindutva Kashmiri Pandit groups outside of Kashmir valley supported this move.
} 
promised: 'There will be a lot of development ... All the citizens will be given their rights' ( $B B C$ News, 2019a). Reflecting the official rationale provided by the Indian government, the move was hailed by its supporters as benefitting women, youth, minorities, marginalised caste and tribal groups, while being opposed only by anti-government political elite (see Singh, 2019). The Indian state, through its constitutional coup, reasserted itself as the patriarch who cares (for a detailed government justification for its action on 5 August, see The Hindu, 2019). The patriarch is represented as the one with privileges that stem from their 'duty of care' as the 'head of the household'; they have the authority to shape, decide or dictate the lives of others because they supposedly know what is best. In fact, the patriarch is often projected as sacrificing their own energies to take care of the 'family' through a mix of love and the iron fist. Likewise, India is represented as 'sacrificing' its security personnel and taking the 'burden of helping' the ingrate Kashmiris (Kapoor, 2019).

Third, there is no let-up in militarisation in Kashmir; in fact, there is heavier militarisation in the region that the CIA (2020) has called 'the world's largest and most militarized territorial dispute'. Violence is integral to colonisation in the same way that it is integral to sustaining a patriarchal rape culture where it is used to discipline and police, make examples of and to instil respect through fear. Tens of thousands of extra troops were sent, newer barricades came up, severe restrictions on gatherings and public assembly were imposed and curfew became a renewed part of everyday life. All the denials of rights were presented by the Indian state as necessary measures to 'secure' Kashmir. This 'securing' of Kashmir for India by brutalising, dehumanising and insecuring the Kashmiris was seen in India as an example of the Modi-led Hindu nationalist government's strong and 'muscular' approach. Cisheteromasculinity depends on the use of violence to police the boundaries of gender and sexuality, and coloniality depends on the use of violence to police the colonised bodies. The Indian patriarchal state uses all forms of violencesystemic, quotidian, exceptional, direct, indirect, epistemic-to try and make Kashmiris accept Indian colonial occupation as normal. These forms include arbitrary detention, pellet-blinding, torture, enforced disappearance, sexual violence, rape and judicial as well as extra-judicial killings. ${ }^{7}$

Fourth, there is enforced silencing. No expression of dissent is permissible. Such enforced silencing that raises the cost of speaking out is integral to patriarchal rape culture where the system functions by making it difficult or costly for the victims to speak up. Colonial occupation too functions by silencing the body politic. In post-August 2019 Jammu and Kashmir, public dissent of any Kashmiri individual or collective constitutional or legal or civic body is not allowed, notwithstanding the crucial role of and right to dissent (even peacefully) in democratic functioning. Politicians, doctors, journalists, civil society activists and the ordinary public are all gagged and/or face intimidation from the state.

Fifth, there is no democratic accountability. The perpetrators of physical and symbolic violence act with impunity knowing that the legal and bureaucratic apparatuses work in their favour. For a significant amount of time, the Supreme Court of India delayed hearing petitions on the momentous changes that amounted to a collective punishment of the Kashmiri population, thus supporting the government's move directly and indirectly through a refusal to immediately require the government to furnish a

\footnotetext{
${ }^{7}$ See Duschinski and Ghosh, 2017; Bhan et al., 2018. See also various reports on violence and human rights abuses at JKCCS, https://jkccs.net/ [last accessed 16 January 2021] and Association of Parents of Disappeared Persons, https://apdpkashmir. $\mathrm{com} /$ [last accessed 16 January 2020]. Even in stark cases of mass rape of girls and women by armed forces such as in the villages of Kunan Poshpora, justice was not served (see Batool et al., 2016).
} 
rationale for their actions. Under the byline 'state of disgrace', The Economist (2019) published an explicit exposure of this in an article: 'India's judges are ignoring the government's abuses in Kashmir'. Over the decades, Kashmir has been treated as a 'state of exception' (Duschinski, 2010; Hassan, 2018).

Sixth, there is a related arbitrariness in how the state decides upon punitive actions and also provides selective respite. With the emergency powers-for instance, the Armed Forces Special Powers Act (AFSPA) (1990) and the Jammu and Kashmir Public Safety Act (PSA) (1978) already in force for decades in Kashmir, there is an institutionalised regime of impunity. This lack of accountability is further enhanced when the state arbitrarily decides to place a blanket ban on communications, then, at different times of its own choosing, temporarily lifts some restrictions for some groups of people; any democratic rights that ought to derive from law become an instrument of manipulation delivered whimsically as an exercise of largesse.

Seventh, there is a divide and rule strategy. As part of the patriarchal rape culture, there is a distinction made between the 'ideal victim' and the rest who have to suffer their experience of being trivialised/ ignored/erased; between 'good women' and 'bad women'. Similarly, under the colonial set-up, the distinction is made between noble and ignoble natives. The entire Kashmir scenario is emphatically stamped with divide et impera; the tactic is evident both in the proximate act of bifurcating Jammu and Kashmir to create two union territories with ethnic and religious cleavages, ${ }^{8}$ and in the continued maintenance of the tragic political divide between Kashmiri Pandits and Kashmiri Muslims, such that the narratives of the histories and memories of both the communities are never seen in the same frame as the common victims of a state that failed them. ${ }^{9}$ Instead, the sufferings of the Kashmiri Pandits are continually referred to as a justification for colonising and dehumanising Kashmiri Muslim bodies.

Eighth, there is the use of humiliation and shame as tools. Honour and shame in patriarchal set-ups are policing mechanisms to control gendered bodies and sexualised identities. In cases of rape, it is often the victim and their family who are seen as having suffered humiliation. Humiliation is indeed manifestly a political exercise. In the case of Kashmir, there is the deliberate humiliation of Kashmiris at every step. The material contours of this multifaceted humiliation are evident through the denial of the right to speak, communicate, dissent, query, access public services, celebrate festivals, earn livelihoods and so on. However, the symbolic humiliation is no less powerful in how it seeks to legislate and erase collective public memory. The symbolic humiliation of individual Kashmiris within and outside of Kashmir is routine, such as the beating up of Kashmiri students on Indian university campuses or the stigmatisation and discrimination when attempting to rent accommodation in Indian cities or hotels. Consider the way in which the BJP (Bharatiya Janata Party) election manifesto promise of 2019 to remove Kashmir's autonomy (see Ghoshal and Kumar, 2019) was carried out, and then followed by PM Modi's proclamation about having inaugurated a 'New Kashmir' (Naya Kashmir in Hindi/Urdu; see Nandini, 2019), thereby ridiculing the indigenous, non-communal and progressive 1944 Kashmiri manifesto of the same name ('New

\footnotetext{
${ }^{8}$ Even prior to August 2019 , a divisive politics was in place. Tarun Upadhyay (2019) refers to the isolation of Kashmir while nurturing Ladakh; however, the August 2019 moves were not welcomed in Kargil, a part of Ladakh (see The Wire, $2019 \mathrm{~b}$ ).

${ }^{9}$ As Karan Thapar (2019) points out, what happened to Kashmiri Pandits in 1990 in Kashmir is remembered, but what happened to Kashmiri Muslims in Jammu in 1947 is forgotten. In 'India's obsession with Kashmir: democracy, gender, (anti)nationalism' (Kaul, 2018), I provide a list of my previous work specifically on the division of the two communities in history and memory and the weaponisation of Kashmiri Pandit identity.
} 
Kashmir' / Naya Kashmir) (see KashmirConnected, 2019 for the text of the 1944 manifesto). ${ }^{10}$ There were reports that significant public buildings such as the Sher-e-Kashmir Stadium (named after Sheikh Abdullah, 'Lion of Kashmir') in Srinagar will be renamed after nationalist figures such as Sardar Patel, who are preferred or appropriated by Hindutva. While Kashmiris were suffering distress under a communications lockdown and Indian opposition political figures were denied entry into Kashmir, the government in India decided to take a group of far-right European MEPs on a tour of the Kashmir Valley (see BBC News, 2019b) -an example of tactical humiliation in the service of Indian coloniality in Kashmir.

Another explicit use of humiliation took place on 5 August 2020-the first anniversary of India's constitutional coup-when Modi laid a silver brick at the Ram temple site in Ayodhya, where an archaeological monument (the Babri Masjid mosque) was demolished by militant Hindu vigilantes in 1992. Laying the foundation for it on the exact day that Kashmir was dismembered and Kashmiri Muslim aspirations were destroyed in the name of development as revenge indicated intentional, trenchant and on-point symbolism-to confirm masculinist possession of a Hindu rashtra/nation over specifically abjected Kashmiri Muslims, and Indian Muslims in general (see Kaul 2017, 2020a). Again, through The Jammu and Kashmir Reorganisation Order Act, 2019 (2019) and related Orders passed in 2020, the Indian state redefined domicile status in Kashmir to extend it to non-Kashmiri residents, who would receive a domicile on an expedited basis if they were resident in the region for a specific number of years. Moreover, on 27 0ctober 2020, new land laws for J\&K came into effect that make it possible for any outsider to buy land in Kashmir. The choice of 27 October was also intentional humiliation, this being the date in 1947 when Indian troops landed in Kashmir Valley and the unrepresentative ruler of Kashmir signed the Instrument of Accession (Jammu and Kashmir) (1947); ${ }^{11}$ it is commemorated as 'a black day' by Kashmiris opposed to Indian occupation.

The features of Indian coloniality in Kashmir I have highlighted here from a feminist perspective-consent, paternalism, violence, enforced silencing, unaccountability, arbitrariness, divide and rule and humiliationwhich are now ever more conspicuous, are underscored by a final feature of a contemporary imperial-colonial project, which frames control as a choice between 'development' or 'freedom': between enhanced economic welfare plus well-being aspirations or political and individual rights, where the 'choice' is forced by the controlling power itself. In patriarchal rape culture, the feminised body has to 'choose' to be either controlled and 'protected' by men from other men or assert independence and thus be 'asking for' sexual and gendered violence. It is the patriarch who often dictates which (non-) choice women and other 'dependants' 'have to make'. Kashmiri demands for freedom are suppressed in the name of the liberatory rationale of development, where the course of action is dictated by the colonising state. 'We must liberate you, we must develop you, even if you do not consent to it!'-this is the mantra of colonialism in Kashmir.

That the mobilisation of development is the most important weapon in the arsenal of patriarchal colonial rule, is a postcolonial reality. I now examine this question of what 'development' means for Kashmiris, and how it has been used to enact a coloniality of Indian control in Kashmir. This 'development' is akin to the 'white man's burden' civilising missions of the European colonial period and is accompanied by Orientalist-style discourses in which Kashmir is exoticised and Kashmiri Muslims are imagined variously

\footnotetext{
${ }^{10}$ This manifesto promised abolition of landlordism, schemes for education and healthcare, equal rights for women, concern for civil liberties, among other things (see Ganai, 2003 for a discussion).

${ }^{11}$ Instrument of Accession of Jammu and Kashmir State (1947) (Jammu and Kashmir-India), signed on 260 ctober 1947 by Maharaja Hari Singh of Jammu and Kashmir and on 27 October 1947 by Lord Mountbatten of Burma, Governor General of India
} 
as excessively religious/beautiful/innocent/corrupt/traitorous/different, and thus perfectly ripe to be 'liberated' by the Indian state from their own excesses (see Malik, 2013). In addition to masculinist and militarised nationalism (Enloe, 2000), this idea of 'liberation' scavenges upon progressive ideas of feminism, LGBTP rights and anti-caste struggles and uses them to gain rhetorical strength, but it is never more than a patriarchal assertion of proprietorial control over a people who are expected to learn to stop resisting and to obey. Econonationalism is integral to Indian colonial rule over Kashmiris, especially since the end of the de jure statehood in August 2019.

\section{econonationalism: what does 'we will develop Kashmir' mean?}

The language of 'development'12 is eminently mutable; it carries connotations of simultaneous desirability in economic, political and social domains. And this is why the uses of a liberatory rationale of development for the purposes of coloniality in Kashmir can be best termed as econonationalism, which works alongside and is related to concepts such as homonationalism (Puar, 2007) and femonationalism (Farris, 2017). Here, I provide an account of how we might be able to perceive this functioning.

Every one of the egregious violations of the rights of Kashmiris is justified in the name of development: in other words, that everything that the masculinist Indian state is doing will ultimately benefit the Kashmiri people themselves. By corollary, it is implied that development is an end that justifies using any means; the means to reaching it do not need to be moral, humane, accountable, consensual or suchlike. Like any hegemonic narrative, the development narrative on Kashmir reconciles multiple contradictions. Those supporting the August 2019 changes aver that they acted to remove all backwardnesses in the Kashmiri society and economy, and to usher in liberatory development. ${ }^{13}$ Somehow, this development-originating in the deprivation of autonomy and statehood and the continued collective punishment of Kashmiris-would create the Panglossian best of all possible worlds. Now, the Kashmiris would have economic growth and better standards of living, young people would have opportunities hitherto denied by the corrupt local elite, the situation of LGBTQ + minorities would be improved, the condition of Dalits would be ameliorated and, quite centrally, women would have more freedom and rights.

To unpack the specious logic of such a framing, it is important to proceed stepwise. One of the first major announcements, within a week of the events of 5 August 2019, was made by the Indian industrialist Ambani, who announced the setting up of a 'development task force' for Kashmir (see Business Today, 2019).14 A further investment summit was planned for October 2019, but then postponed, and

\footnotetext{
${ }^{12}$ Here, I signal the post-development critique that followed Arturo Escobar's (1995) powerful deconstruction of the imaginary of development as a chapter in the anthropology of modernity.

${ }^{13}$ All this while the moves actually inflicted crippling losses on the economy of Kashmir. A report by the Kashmir Chamber of Commerce and Industry $(\mathrm{KCCl})$ assessed the losses to the Kashmir economy in the four months after August 2019 to be Rs $17,878.18$ crores (PTI, 2019).

${ }^{14}$ The next day, a deal was brokered between Ambani's Reliance and Saudi Aramco (see Raval and Parkin, 2019). The Economic Times reported on 16 August 2019 that in the two days after the 12 August 2019 AGM, Ambani's wealth had increased by US\$4 billion (Rs 28,684 crore) (ETMarkets.com, 2019).
} 
subsequently reports surfaced to the effect that contracts were being given to Indian rather than Kashmiri companies. With Marnia Lazreg (2002, p. 134), one might say 'Development today means the establishment of capitalist economies'. In Kashmir, 2020 saw further amendments to law and policies allowing non-citizens to obtain a residency-based domicile status on a fast-tracked basis and allowing outsiders to buy land; designation of any area as strategic, thus enabling permanent constructions there for the use of the armed forces; and plans for building hundreds of thousands of different dwellings under the changed housing and urban development policy. Kashmiris fear that all these changes taken together will result in overwhelming demographic change and outsider settlements. ${ }^{15}$

It is perfectly possible to have increased economic growth (higher GDP) alongside increased joblessness, widening inequalities, environmental destruction and pollution and a poorer quality of life. Development, quite literally, refers to an improvement in the quality of life that people are leading as measured by various different indicators. In this sense, it has been pointed out by many, including the economist Jean Dreze, that the socio-economic indicators for Jammu and Kashmir are much better than for many Indian states, including PM Modi's home state of Gujarat (see Vincent, 2019). Workers from many Indian states seasonally migrate to Kashmir to earn a living. The kind of begging and homelessness that is ubiquitous in India is rare in Kashmir. What the promised economic growth might mean in the context of Kashmir is more likely to be high-risk, high-return investments in selected sectors of a corrupt conflict economy with possibly irreversible and damaging impacts on forestry, land and natural resources; ${ }^{16}$ this should be a prime concern internationally, owing to the many transborder dimensions of the high-altitude ecosystem. This is in addition to the pre-existing land grabs in a conflict zone (Suhail, 2018).

Next, it is thoroughly problematic to justify the deprivation of collective Kashmiri freedoms through appeal to LGBTQ + rights. The prevalence of homophobia is a shared feature of Kashmiri and wider Indian societies, and there must be every effort to combat this, including by supporting the LGBTP + community individuals and organisations in Kashmir. It was only in 2018 that homosexuality was decriminalised in India, and the Supreme Court judgment on Section 377 is applicable to J\&K as well (see Outlook Bureau, 2018). ${ }^{17}$ The present actions, colonial as they are, appeared to be premised on an understanding that the LGBTP + Kashmiris are somehow not also Kashmiri individuals. They ignore the detrimental impact of state-imposed siege on LGBTP + Kashmiris (see Bhat, 2019). In seeking to justify Indian oppression through the claim to liberate a marginalised Kashmiri minority (for an example of this, see Oplndia, 2019), this becomes an instance of homonationalism (for an undoing of this fabricated link, see Gawande, 2019; Upadhyay, 2020). The central dynamic in using the rights of sexual minorities to oppress others rests upon the idea of what Judith Butler (2008) terms a 'presumptive modernity', and the Indian position illustrates this well. In the Indian context, instances of homonationalism are witnessed not in the state's own rhetoric but amongst nationalists who seek to represent the state as progressive despite it being staunchly regressive and conservative Hindu nationalist.

\footnotetext{
${ }^{15}$ In November 2019, the Indian Consul General in New York, Sandeep Chakravorty (quoted in Express News Service, 2019), was filmed at an event as he compared the return of Kashmir's Hindu minority to Israeli settlements, stating 'If the Israeli people can do it, we can also do it'.

${ }^{16}$ Athar Parvaiz (2019a) reports that the "J\&K administration has stepped up efforts to create "land banks" for investors from outside Kashmir Valley. Over 7\% of government-owned land in the valley has already been identified for this purpose: 15,000 acres out of 203,020. Most of the plots identified are in the floodplains of or adjacent to rivers, streams and wetlands' (see also Parvaiz, 2019b).

${ }^{17}$ Navtej Singh Johar \& Others v. Union of India (2018) 10 SCC I (India)
} 
Analogously, some held that the removal of statehood was necessary in order to remove the privileges of the Kashmiri 'state subjects', which made others such as the landless labour and Dalits unable to secure similar livelihoods. This assumption of backward Kashmiri society requiring liberation by a progressive modern Indian state ignores the history of progressivism and contestations within Kashmir itself. For instance, in the early 1950s, important land reforms were carried out in Kashmir that were far more progressive and extensive than in India. Nawal Kishor Kumar (2019) quotes R.K. Kalsotra (a member of the All India Confederation of SC, ST, OBC, J\&K, who has worked for the rights of the Scheduled Caste, Scheduled Tribe and Other Backward Classes communities since 1990), thus: 'The government of Hindustan is targeting the people of Jammu and Kashmir by placing the gun on the shoulders of Dalit, Adivasi and OBC people'. The siege imposed by the state in August 2019 had devastating effects across society, causing staggering (in)direct losses to the economy of J\&K. It is the marginalised and impoverished who have likely borne the disproportionate brunt of intentional immiserisation.

Finally, nowhere else is the implication of the liberation rationale of development as linked into the coloniality of India in Kashmir as in the question of gender and, more specifically, Kashmiri women. Any colonial move in the name of the nation is always deeply imbricated in subjugating the Other through the gendered exercise of hierarchical power. An argument widely heard in the Indian public sphere following August 2019 was that what had been done to Kashmir was in order to enhance the rights and freedoms of Kashmiri women. ${ }^{18}$ It was (inaccurately) claimed that Kashmiri women who marry nonKashmiri men lose their state subject status. This restriction, though originally present, was struck down in the judgment of the Jammu \& Kashmir High Court on the State of Jammu \& Kashmir and Others versus Susheela Sawhey and Others inheritance case of 7 October 2002 (see Qureshi, 2019). ${ }^{19}$ The reason for this, as for the provision of the 'state subject' as an entity, was and has always been to prevent changes to the economic and demographic character of the state, whose accession to the Indian Union was linked to the conduct of a plebiscite, which was never carried out. Of essence is the fact that Kashmir is a political dispute; indeed, it was one of the first international issues in which the UN was comprehensively involved during the middle decades of the twentieth century. Instead of the stop-and-start bilateral attempts to resolve it-as were carried out by previous regimes with varying levels of success-the present Indian regime, emboldened by its second win in the general elections, is acting straightforwardly upon the Hindutva dream for the region (Kaul, 2019).

The patriarchal state's claim to women's empowerment is not new. Samreen Mushtaq and Syed Rabia Bukhari (2018) have provided a sharp critique of the ways in which women's empowerment is being used by the Indian state in Kashmir. They ask, 'An important ethical question, then, is: how can the same state that employs violence, denies justice, kills, blinds, and rapes with impunity, claim to be empowering people in general and women in particular?' (ibid., p. 87). They argue that in the manner of colonial narratives, the empowerment of women is used by the Indian state to hide the violations and paper over the question of legitimacy. Indeed, feminism, like other progressive ideologies, is open to being subverted in content while being deployed in name.

\footnotetext{
${ }^{18}$ This echoes the rationale used by the British to deny self-rule to Indians. See Ravina Aggarwal's 'Trails of turquoise: feminist enquiry and counter-development in Ladakh, India' (2002, pp. 75, 84) for previous feminist critiques of colonial rule: 'The British used "the woman question" to argue that Indian society was incapable of self-rule'.

${ }^{19}$ State of Jammu \& Kashmir and Others v. Dr Susheela Sawhey and Others (2003) AIR 2003 J\&K, 2003 (1) JKJ 35 (India)
} 
If, for decades, Kashmir was claimed in the name of democracy, now it has been colonised in the name of development. None of the liberatory developmental rationales of economic and social welfare or amelioration of the rights of sexual, economic and gender minorities hold up to scrutiny, or justify the multidimensional collective punishment, rights abuses and continued oppression. In fact, much of the 'liberation talk' remains at the level of rhetoric deployed by defenders of the government and does not even filter through to policy formulation. As India made its move in Kashmir in August 2019 and Kashmiris were silenced en masse, numerous Indians celebrated their 'ownership' of Kashmir, Kashmiri women and/as property.

Even Indian commentators noticed this, for instance, 'In most tweets and posts, Indians seem to be equating property with women' (Mukherjee, 2019). One particularly troubling reason for the celebration amongst the backers of this move was the predatory fetishisation and objectification of Kashmiri women. Ruling BJP MLA (Member of Legislative Assembly) Vikram Singh Saini from India's most populous state of Uttar Pradesh was filmed making the remarks at a rally that 'BJP workers were "excited" by the change as they can now marry "fair girls from Kashmir"' (The Wire, 2019a). In fact, Scroll.in (2019b) reported that a whole new sub-genre of songs emerged in India about getting Kashmiri bahus (daughtersin-law) and buying land in the Valley. The Indian state's political move thus resonated with the creation and consolidation of sexualised and gendered fantasies. I theorise this long-standing Indian obsession with Kashmir through a feminist analysis focusing on the discourses of representation, cartography and possession-the 'exotic' Kashmiri women, Kashmir as the head of the geo-body of 'Mother India' and a feminised understanding of possession and control of Kashmiri bodies to bring order to the troubled 'marital relationship' between India and Kashmir (Kaul, 2018).

The nationalist project in India, as elsewhere, is deeply gendered, and the Hindu nationalist project of the BJP on Kashmir is filled with contradictions in how it combines coloniality with social conservatism as well as the language of liberation (on various aspects, see Kaul and Zia, 2018; Dhar, 2019; Mushtaq, 2019; Naqvi, 2019). Astoundingly, BJP legislators and supporters marched in support of the Hindu rightwing alleged rapists of Asifa Bano, an 8-year-old girl, in 2018 in Kathua, Jammu. Soon thereafter, at a festival celebrating the Hindu epic of the Ramayana in September 2019, the Indian Home Minister Amit Shah said, citing the Ramayana: 'How is a woman's honour protected ... Those who understand the horrors of war and its devastating consequences also say that when a woman's honour is lost, the state is lost, culture is lost. That's why if a war is necessary to protect a woman's honour, it must be fought' (see Pandey, 2019). Violence and control in the name of the 'protection' of women are part of patriarchal rape cultures and masculinist nationalisms.

Despite the overwhelming acceptance within India of the right-wing government's constitutional coup in Kashmir, the fact remains that the move is part of a toxic nationalism that operates with an often violently and coercively enforced Hindu supremacism making political use of religion, along with hypocritical doubletalk on gender, and is comprised of the usual discourse of liberating women and the fantasies of possessing women as property. The aim is to realise the dream of a Hindu nation for the supporters of such a project and to deliver economic exploitation by way of resource grabs for its crony backers, ${ }^{20}$ in this case by treating Kashmir as real estate and as unpeopled.

\footnotetext{
${ }^{20}$ The wealth of Modi's biggest corporate backers, the industrialists Ambani and Adani, has doubled under his rule; for more, see Varma, 2019.
} 


\section{why does econonationalist development function as a successful mode of coloniality in Kashmir?}

In the contemporary post-August 2019 phase, it has become clear that 'development' can successfully be mobilised to entrench an occupation; every indicator seems to point to the destruction of the economy and livelihoods that came about as a result of this ostensibly development-promoting move. Once we are able to perceive the ways in which the rhetoric of development can be, and has been, used to justify the exercise of power as coloniality in Kashmir, we must ask why 'development' functions as a successful mode of coloniality in the face of enough empirical evidence that demonstrates the oppressions and dehumanisations carried out in its name. In other words, what underpins the appeal of econonationalism?

I want to offer brief conceptual, ideological and historical explanations here. Namely, that development has come to be understood as a transitive verb: it is something done to people to address their (often feminised) Othered forever-lack, rather than something done by them; it functions as an apolitical marker while being thoroughly ideological in how it separates the political from the economic realm; and it has been entrenched through institutions and powerful global and national actors serving historical and contemporary imperial-colonial projects that have validated oppressions in its name.

First, conceptually, the dominant way in which development is seen ever more is as a transitive verb-as something that is done to someone, rather than as something done by them (see Arndt, 1981). Hence, we have the idea of bringing development to a place or a people. Further, implied within the idea of such development is a teleology; the rhetoric of development constructs it as something that progressively unfolds in a hierarchical manner (from those who are more developed to those who are less developed) in order to address an always-already forever-lack. In both of these senses, the imaginary is that of an Other who is always backward (constructed as uncivilised, feminised, impoverished, in need of guidance and instruction) and a potential beneficiary of the liberation that development will bring in whatever manner and through whatever means that might need to be endured to reach the desired goal of achieving development.

Second, ideologically, development is seen as an all-round panacea, something that is a precursor to purported peace and the end of conflict in and of itself, because it is somehow apolitical. For instance, the simplistic link made between impoverishment and political radicalisation in Kashmir, i.e. that if Kashmiri youth were educated and well-off then their political aspirations for freedom or the end of Indian occupation would vanish, is deeply problematic and not borne out in reality. However, it is a persuasive construct because it presents a facile hope out of a conflicted and unending imbroglio. By transferring the question of politics of freedom onto a circumstantial terrain, and by functioning as an ostensibly apolitical referent, the idea of development holds out the promise that economic growth (even if it were realisable under the present circumstances in Kashmir) is the same as development, and thus seeks to depoliticise the fundamentally political questions of freedom, value, work and reward (Kaul, 2007).

Third, historically, as a result of the long-standing history of Bretton Woods institutions and the successful invention of development as the new civilising mission in the Foucauldian sense of 'useful delinquency' (one that permits intervention) (Foucault, 1995 [1977], pp. 277-280) in the post-Second World War era, development (like democracy in its procedural, as opposed to substantive, sense) has 
been a valuable weapon in the arsenal of profitable commercial and military interventions that speak to (trans)national interests. Notwithstanding the attempts by China, at the behest of Pakistan, to raise the Kashmir issue in the UN Security Council, the current Indian moves in Kashmir echo not just the historical colonialism of the British Empire but also the contemporary Chinese establishment of control over Tibet and Xinjiang through infrastructure, demographic and other economic changes (see Kaul, 2020b). The fact that these and other moves have been successful geopolitically through validation by powerful international states does not (and should not) obfuscate the denial of rights and freedoms that they involve.

\section{conclusion}

By way of conclusion, I would like to put forth a few thoughts. It is worth wondering that if the oftrepeated statement that 'Kashmir is an integral part of India' is the answer, then what is the question? Only a situation of coloniality can assert such a stake-claiming answer in a context of disputed relationality. A careful look at the history of the region would make clear the legal claims of those speaking the name of the entity 'Kashmir'. At present, the vital link between state and statistics is enacted through the necropolitical ${ }^{21}$ arithmetic enabled by the use/deployment of terror as a master narrative. It is impossible to ignore the entrenched use of arbitrary power to enact different modalities of killing and maiming Kashmiris by a patriarchal masculinist colonial state.

At the time of this writing, the future outcomes in the region are held hostage to the playing out of a tactical gambit with a bet on different combinations of indignation and resignation. It is deemed acceptable to do this precisely because Kashmiri lives and aspirations do not matter in these calculations. While claiming to bring liberatory and multidimensional development to Kashmir, the post-August 2019 period has witnessed the wilful imposition of destitution upon Kashmiris by a conscious crippling of the economy of Kashmir, economic violence, genocidal fears and the creation of continued debility, while deploying the rhetoric of liberation and development for all, but specifically for women, LGBTQ + people and minorities. All of this relies upon the perpetuation of sustained divides between Kashmiris of different regions and religions, media limitations, suppression of dissent and free speech by intimidation and violence, and the lack of systematic knowledge and wider understanding of Kashmir as a political dispute. If these be the facts of the matter, then let us call econonationalism and other discourses serving an occupation by their true name: coloniality.

\section{acknowledgements}

I would like to thank the referees, editors and everyone else who has worked to finalise this manuscript on behalf of the journal.

\section{author biography}

Nitasha Kaul (PhD, MSc, BA Hons) is a multidisciplinary academic, novelist, poet, artist and economist. Over the last two decades, she has researched and published extensively on themes relating to

\footnotetext{
${ }^{21}$ I use necropolitical here as theorised by Achille Mbembe (2003).
} 
democracy, political economy, identity, rise of right-wing nationalism, feminist and postcolonial critiques, Bhutan, India and Kashmir. Her books include Imagining Economics Otherwise (Routledge, 2007), Future Tense (Harper Collins India, 2020), Man-Asian Literary Prize shortlisted Residue (Rainlight, 2014) and Can You Hear Kashmiri Women Speak? (co-edited; Kali for Women Press, 2020). Currently, she is a Reader (Associate Professor) in Politics and International Relations at the Centre for the Study of Democracy, University of Westminster in London. She writes and speaks within and outside academia. www. nitashakaul.com

\section{references}

Aggarwal, R., 2002. Trails of turquoise: feminist enquiry and counter-development in Ladakh, India. In K. Saunders, ed. Feminist Post-Development Thought: Rethinking Modernity, Post-colonialism and Representation. London: Zed Books, pp. 69-86.

Armed Forces (Jammu and Kashmir) Special Powers Act, 1990 (AFSPA), 1990. Act No. 21 of 1990. New Delhi: Parliament of India, Government of India. Available at: http://indiacode.nic.in/bitstream/123456789/1953/1/199021.pdf\#search=Armed\%20 forces\%201990 [last accessed 13 February 2018].

Arndt, H.W., 1981. Economic development: a semantic history. Economic Development and Cultural Change, 29(3), pp. $457-466$.

Batool, E., Butt, I., Rashid, M., Rather, N. and Mushtaq, S., 2016. Do You Remember Kunan Poshpora? New Delhi: Zubaan.

BBC News, 2019a. Kashmir dispute: India PM Modi defends lifting special status. BBC News, 8 August. Available at: https://www. bbc.co.uk/news/world-asia-india-49275789 [last accessed 20 April 2020].

$B B C$ News, $2019 b$. Outrage over right-wing Euro-MPs' Kashmir visit. BBC News, 30 0ctober. Available at: https://www. bbc.co.uk/ news/world-asia-india-50231022 [last accessed 16 January 2020].

Bhambra, G.K., 2014. Postcolonial and decolonial dialogues. Postcolonial Studies, 17(2), pp. 115-121.

Bhan, M., Duschinski H. and Zia, A. 2018. "Rebels of the streets": violence, protest, and freedom in Kashmir. In H. Duschinski, M. Bhan, A. Zia and C. Mahmood, eds. Resisting Occupation in Kashmir. Philadelphia: University of Pennsylvania Press, pp. 1-4l.

Bhat, A., 2019. In India, Kashmir's transgender community struggles to survive under the shadow of conflict. South China Morning Post, 28 September. Available at: https://www.scmp.com/week-asia/article/3030655/india-kashmirs-transgendercommunity-struggles-survive-under-shadow [last accessed 18 April 2020].

Business Today, 2019. Mukesh Ambani's RIL to form task force to invest in J\&K, Ladakh after PM Modi's request. Business Today, 12 August. Available at: https://www.businesstoday.in/current/corporate/mukesh-ambani-ril-form-task-force-invest-jkladakh-pm-modi-request/story/372039.html [last accessed 16 January 2020].

Butler, J., 2008. Sexual politics, torture, and secular time. The British Journal of Sociology, 59(1), pp. 1-23.

Central Intelligence Agency (CIA), 2020. Disputes - international. The World Factbook, 15 July. Available at https://www.cia. gov/the-world-factbook/field/disputes-international/ [last accessed 16 January 2021].

Citizenship (Amendment) Act, 2019 (CAA), 2019. Act No. 47 of 2019. New Delhi: Parliament of India, Government of India.

Code of Criminal Procedure, 1973 (CrPC), 1973. Act No. 2 of 1974. New Delhi: Parliament of India, Government of India.

Dhar, P., 2019. History tells us the Kashmir crisis will be particularly dangerous for women - so why aren't we talking about it? The Independent, 21 August. Available at: https://www.independent.co.uk/voices/kashmir-crisis-india-pakistan-bjpwomen-kunan-poshpora-a9072766.html [last accessed 16 January 2020].

Duschinski, H., 2010. Reproducing regimes of impunity. Cultural Studies, 24(1), pp. 110-132.

Duschinski, H. and Ghosh, S.N., 2017. Constituting the occcupation: preventative detention and permanent emergency in Kashmir. The Journal of Legal Pluralism and Unofficial Law, 49(3), pp. 314-337. 
Enloe, C., 2000. Bananas, Beaches and Bases: Making Feminist Sense of International Politics. Berkeley: University of California Press.

Escobar, A., 1995. Encountering Development: The Making and Unmaking of the Third World. Princeton: Princeton University Press.

Essential Commodities (Amendment) Act, 2020, 2020. Act No. 22 of 2020. New Delhi: Parliament of India, Government of India.

ETMarkets.com, 2019. Mukesh Ambani gets richer by Rs 29,000 crore in 2 days. The Economic Times, 16 August. Available at: https://economictimes. indiatimes.com/markets/stocks/news/mukesh-ambani-gets-richer-by-rs-29000-crore-in-2days/articleshow/70690180.cms [last accessed 16 January 2020].

Express News Service, 2019. Indian diplomat compares return of Kashmiri Pandits with Israeli settlements, sparks row. The Indian Express, 28 November. Available at: https://indianexpress.com/article/india/indian-diplomat-compares-returnof-kashmiri-pandits-with-israeli-settlements-sparks-row-6140271/ [last accessed 3 August 2020].

Farmers (Empowerment and Protection) Agreement on Price Assurance and Farm Services Act, 2020, 2020. Act No. 20 of 2020. New Delhi: Parliament of India, Government of India.

Farmers' Produce Trade and Commerce (Promotion and Facilitation) Act, 2020, 2020. Act No. 21 of 2020. New Delhi: Parliament of India, Government of India.

Farris, S., 2017. In the Name of Women's Rights: The Rise of Femonationalism. Durham: Duke University Press.

Foucault, M., 1995 [1977]. Discipline and Punish: The Birth of the Prison. Tr. A. Sheridan. New York: Pantheon Books.

Ganai, M.Y., 2003. Kashmiri Nationalists and their vision (1931-1947). Proceedings of the Indian History Congress, 64, pp. 1003-1014.

Gawande, A., 2019. The false link between Article 370 and queer rights. The Wire, 6 September. Available at: https://thewire. in/lgbtqia/all-you-need-to-know-about-the-false-link-between-article-370-and-queer-rights [last accessed 16 January 2020].

Ghoshal, D. and Kumar, M., 2019. Modi makes election vow to remove Kashmir's special rights. Reuters, 8 April. Available at: https://www.reuters.com/article/india-election-kashmir-idUSKCNIRK0JS [last accessed 16 January 2020].

Haddad, T., 2019. Kashmir: Twitter removes almost 1 million tweets, accused of bowing to Indian censorship. Newsweek, 25 October. Available at: https://www.newsweek.com/twitter-removes-almost-lm-tweets-kashmir-accused-bowing-indian-censorship-1467721 [last accessed 16 January 2020].

Hassan, K.W., 2018. From administration to occupation: the re-production and subversion of public spaces in Kashmir. Third World Thematics, 3(2), pp. 212-227.

Jammu and Kashmir Public Safety Act, 1978 (PSA), 1978. Act No. 6 of 1978. New Delhi: Parliament of India, Government of India. Available at: https://www.refworld.org/docid/3ae6b52014.html [last accessed 10 February 2021].

Kapoor, V., 2019. Stop wailing and tell us how to resolve the Kashmir issue. The Sunday Guardian, 24 August. https://www.sundayguardianlive.com/opinion/stop-wailing-tell-us-resolve-kashmir-issue [last accessed 12 April 2020].

KashmirConnected, 2019. New Kashmir: the English text in full. KashmirConnected, 26 October. Available at http://www. kashmirconnected.com/resources/new-kashmir-the-english-text-in-full [last accessed 16 January 2020].

Kathju, J., 2019. No social media, full data access to cops: Kashmir internet to come with 6 conditions. The Wire, 5 September. Available at: https://thewire.in/government/kashmir-internet-bond [last accessed 16 January 2020].

Kaul, N., 2007. Imagining Economics Otherwise: Encounters with Identity/Difference. London: Routledge.

Kaul, N., 2017. Rise of the political right in India: Hindutva-development mix, Modi myth, and dualities. Journal of Labor and Society, 20(4), pp. 523-548.

Kaul, N., 2018. India's obsession with Kashmir: democracy, gender, (anti)nationalism. Feminist Review, 119, pp. 126-143. 
Kaul, N., 2019. Kashmir is under the heel of India's colonialism. Foreign Policy, 13 August. Available at: https://foreignpolicy. com/2019/08/13/kashmir-is-under-the-heel-of-indias-colonialism/ [last accessed 16 January 2020].

Kaul, N., 2020a. Islamophobia in India. Society and Space, 7 December. Available at: https://www.societyandspace.org/articles/islamophobia-in-india [last accessed 8 December 2020].

Kaul, N., 2020b. China: Xinjiang :: India: Kashmir. Made in China Journal, 5 October. Available at: https://madeinchinajournal. com/2020/10/05/china-xinjiang-india-kashmir/ [last accessed 11 December 2020].

Kaul, N. and Zia, A., 2018. Knowing in our own ways - women and Kashmir. Economic and Political Weekly, 53(47), pp. 33-35.

Kumar, N.K., 2019. Government is firing from the shoulders of Dalits, Adivasis, OBCs: RK Kalsotra on Article 370. The Caravan, 13 November. Available at: https://caravanmagazine.in/politics/jammu-kashmir-obc-dalit-tribal-kalsotra-english [last accessed 16 January 2020].

Lazreg, M., 2002. Development: feminist theory's cul-de-sac. In K. Saunders, ed. Feminist Post-Development Thought: Rethinking Modernity, Post-colonialism and Representation. London: Zed Books, pp. 123-145.

Malik, I., 2013. The Muslim woman's struggle for justice. Seminar, 4 April. Available at: https://www.india-seminar. com/2013/643/643_inshah_malik.htm [last accessed 16 January 2020].

Mbembe, A., 2003. Necropolitics. Public Culture, 15(1), pp. 11-40.

Mukherjee, J., 2019. Patriarchy in garb of patriotism: desperate men rush to 'find' Kashmiri girls after Article 370 is revoked. News 18, 6 August. Available at: https://www.news 18.com/news/buzz/patriarchy-in-garb-of-patriotism-desperatemen-rush-to-find-kashmiri-girls-after-article-370-is-revoked-2260371.html [last accessed 16 January 2020].

Mushtaq, S., 2019. Militarisation, misogyny and gendered violence in Kashmir. LSE Engenderings Blog, 9 September. Available at: https://blogs.Ise.ac.uk/gender/2019/09/09/militarisation-kashmir/ [last accessed 16 January 2020 ].

Mushtaq, S. and Bukhari, S.R., 2018. Critique of the state's narrative of women empowerment in Kashmir. Economic \& Political Weekly, 53(2), pp. 82-87.

Nandini, N., 2019. PM Modi coins Kashmir slogan; tells India 'Naya Kashmir banana hai'. RepublicWorld.com, 19 September. Available at: https://www.republicworld.com/india-news/general-news/pm-modi-coins-kashmir-slogan-tells-indianaya-kashmir-banana-hai.html [last accessed 16 January 2020].

Nandy, A., 1983. The Intimate Enemy: Loss and Recovery of Self Under Colonialism. New York: Oxford University Press.

Naqvi, F., 2019. For the BJP, 'women's rights' are really all about the men. The Wire, 24 April. Available at: https://thewire.in/ women/elections-2019-bjp-womens-rights [last accessed 16 January 2020].

OpIndia, 2019. LGBT Rights Advocacy Group trolled by people from the LGBT community for celebrating the complete integration of JK. OpIndia, 6 August. Available at: https://www.opindia.com/2019/08/lgbt-rights-advocacy-group-trolled-bypeople-from-the-Igbt-community-for-celebrating-the-complete-integration-of-jk/ [last accessed 18 April 2020 ].

Outlook Bureau, 2018. Supreme Court Judgment on Section 377 applicable to J\&K, say legal experts. Outlook, 7 September. Available at: https://www.outlookindia.com/website/story/sc-judgment-on-377-applicable-to-jk/316214 [last accessed 16 January 2020].

Pandey, N., 2019. War must be fought if needed to protect woman's honour, says Amit Shah citing Ramayana. The Print, 17 September. Available at: https://theprint.in/politics/war-must-be-fought-if-needed-to-protect-womans-honoursays-amit-shah-citing-ramayana/293057/ [last accessed 16 January 2020].

Parvaiz, A., 2019a. Under President's rule, J\&K has given up 243 hectares of forest land for army and paramilitary use. Scroll.in, 16 December. Available at: https://scroll.in/article/946888/under-presidents-rule-jammu-kashmir-is-axing-1471trees-in-designated-forests [last accessed 16 January 2020 ].

Parvaiz, A., 2019b. Indian government looks to acquire land in Kashmir. The Third Pole, 20 December. Available at: https://www. thethirdpole.net/en/2019/12/20/indian-government-looks-to-acquire-land-in-kashmir/ [last accessed 16 January 2020 ]. 
PTI, 2019. Kashmir economy suffered loss of Rs $17,878 \mathrm{cr}$ in 4 months after Article 370 abrogation. The Indian Express, 17 December. Available at: https://indianexpress.com/article/india/kashmir-economy-suffered-loss-four-months-afterarticle-370-abrogation-jk-6172096/ [last accessed 16 January 2020].

Puar, J.K., 2007. Terrorist Assemblages: Homonationalism in Queer Times. Durham: Duke University Press.

Qureshi, A., 2019. Using women to justify the removal of Article 370. The Citizen, 240 ctober. Available at: https://www.thecitizen.in/index.php/en/NewsDetail/index/7/17763/Using-Women-to-Justify-the-Removal-of-Article-370 [last accessed 16 January 2020$]$.

Raval, A. and Parkin, B., 2019. Saudi Aramco deepens Indian ties with Reliance partnership. Financial Times, 13 August. Available at: https://www.ft.com/content/95ee8b64-bdla-1le9-b350-db00d509634e [last accessed 16 January 2020 ].

Sartre, J-P., 2001 [1964/1956]. Colonialism is a system. In J-P. Sartre Colonialism and Neocolonialism. London: Routledge, pp. $30-47$.

Scroll.in, 2019a. Eight states have had internet shutdowns in last one month, Kashmir enters 135th day of blockade. Scroll.in, 17 December. Available at: https://scroll.in/latest/947074/eight-states-have-had-internet-shutdowns-in-last-onemonth-kashmir-enters-135th-day-of-blocks [last accessed 16 January 2020].

Scroll.in, 2019b. Watch: a whole new sub-genre of songs emerges about getting Kashmiri bahus, buying land in Valley. Scroll.in, 12 August. Available at: https://scroll.in/video/933520/watch-there-is-a-whole-new-sub-genre-of-songs-inspiredby-kashmir-and-the-article-370-controversy [last accessed 16 January 2020].

Singh, A.P., 2019. Removing Art 370 an act of emancipation: Dalits, women and tribals of J\&K will now get their due. Swarajya Magazine, 6 August. Available at: https://swarajyamag.com/politics/in-victory-of-hindutva-370-goes-minoritieswomen-dalits-and-tribals-of-jk-get-their-due [last accessed 16 January 2020].

Spencer-Wood, S.M., 2016. Feminist theorizing of patriarchal colonialism, power dynamics, and social agency materialized in colonial institutions. International Journal of Historical Archaeology, 20(3), pp. 477-491.

Suhail, P.G.N., 2018. Pieces of Earth: The Politics of Land-Grabbing in Kashmir. New Delhi: Oxford University Press.

Thapar, K., 2019. We cannot be selective about the past in Jammu \& Kashmir. Hindustan Times, 15 September. Available at: https://www.hindustantimes.com/columns/we-cannot-be-selective-about-the-past-in-j-k/story-ELfaDpC6UoAfMbB NQTgls0.html [last accessed 16 January 2020].

The Economist, 2019. India's judges are ignoring the government's abuses in Kashmir. The Economist, 5 October. Available at: https://www.economist.com/asia/2019/10/05/indias-judges-are-ignoring-the-governments-abuses-in-kashmir [last accessed 16 January 2020].

The Hindu, 2019. Full text of document on govt.'s rationale behind removal of special status to J\&K. The Hindu, 5 August. Available at: https://www.thehindu.com/news/national/full-text-of-document-on-govts-rationale-behind-removal-of-specialstatus-to-jk/article28821368.ece [last accessed 16 April 2020].

The Jammu and Kashmir Reorganisation Order, 2020. Act No. 34 of 2019. New Delhi: Ministry of Home Affairs, Government of India. Available at: https://lexcomply.com/rsjadmin/news/2020101034020rder\%20S.0.\%203466(E)-Union\%20Territory\%200f\%20 J\%20\&\%20K\%20Reorganisation\%20(Adaptation\%200f\%20Central\%20Laws)\%203rd\%200rder\%202020.pdf [last accessed 4 June 2021].

The Wire, 2019a. BJP workers excited to marry fair girls from Kashmir, says UP MLA. The Wire, 7 August. Available at: https:// thewire.in/politics/vikram-saini-bjp-kashmir-article-370 [last accessed 16 January 2020].

The Wire, 2019b. Hartal in Kargil against centre's decision to read down 370, make Ladakh a UT. The Wire, 7 August. Available at: https://thewire.in/politics/kargil-ladakh-hartal-article-370-jammu-and-kashmir [last accessed 16 January 2020 ].

The Wire, 2019c. In Kashmir, freedom at a price: go back to jail if you speak or comment on Article 370. The Wire, 210 ctober. Available at: https://thewire.in/rights/kashmir-freedom-at-a-price-go-back-to-jail-if-you-speak-or-comment-onarticle-370 [last accessed 16 January 2020]. 
Upadhyay, T., 2019. 'Division' politics in J\&K: isolating Kashmir by nurturing Ladakh. Outlook India, 10 February. Available at: https://www.outlookindia.com/website/story/india-news-division-politics-in-jk-isolating-kashmir-by-nurturingladakh/325217 [last accessed 16 January 2020].

Upadhyay, N., 2020. Hindu nation and its queers: caste, Islamophobia, and de/coloniality in India. Interventions, 22(4), pp. 464-480.

US House of Representatives, Committee on Foreign Affairs, 2019. Human Rights in South Asia: Views from the State Department and the Region, Panel II. Hearing, 22 0ctober. Washington: Government Printing Office. Available at: https://foreignaffairs. house.gov/2019/10/human-rights-in-south-asia-views-from-the-state-department-and-the-region [last accessed 16 January 2020].

Varma, S., 2019. Under Modi rule, Ambani, Adani have doubled their wealth. Newsclick, 13 0ctober. Available at: https://www. newsclick.in/Under-Modi-Rule-Ambani-Adani-Have-Doubled-Their-Wealth [last accessed 16 January 2020].

Vincent, P.L., 2019. Jean Dreze contests Amit Shah with Gujarat data. Telegraph India, 9 August. Available at: https://www.telegraphindia.com/india/jean-dreze-contests-amit-shah-with-gujarat-data/cid/1696457 [last accessed 16 January 2020 ]. 